\title{
REDUCING SURFACE IRRIGATION WATER LOSSES IN THE NILE DELTA
}

\author{
M. A. El-Adl'; M.M. Ibrahim² ; \\ W. H. Abo El Hassan ${ }^{3}$, and H. M. Abd El Baki ${ }^{4}$
}

ABSTRACT

Due to the serious water shortages the saving of irrigation water is very important, particularly in countries with limited water like as Egypt. A field experiment was conduct during the summer season of 2012 at ElKarada Water Research Station, Water Management and Irrigation Systems Research Institute, Kafr El-Sheikh, Egypt. This research aims to study the effect of new method of mulching on water saving and yield of maize. Four treatments were tested : no mulch (control) (A); straw mulch (B); $30 \%$ plastic mulch $(C)$, and $60 \%$ plastic mulch (D). Mulching was performed with 30 and $60 \%$ furrows preimeter, along $50 \%$ furrows length. Applied irrigation water (AIW), water advance time (WAT), soil moisture content (SMC), water use efficiency (WUE), application water efficiency $\left(E_{a}\right)$, ground water level $(G W L)$, and grain yield $(G Y)$ were computed.

Results showed that both treatments $D$ and $C$ decreased AIW about of $24.65 \%$ and $21.65 \%$, while straw mulch treatment increased AIW about of $3.37 \%$ compared with control treatment. Both treatments of $C$ and $D$ reduced (WAT) with 20.9 and $21.3 \%$, while treament of B increased it with $19.1 \%$ compared with control treatment. Plastic mulch had siginficantly effect on SMC which the minimum values were recorded under treatments of $D$ and $C$, respectively. On the other hand, highest values of SMC were obtained under straw mulch treatment. It was observed that WUE had the highest value under treatments $C$ and $D$, respectively. While, the lowest value was obtained under straw mulch treatment. Application water efficiency invistegated the highest values under treatment of $C$ and B, respectively. But, it had the lowest values under control treatment. Results of GWL indicated that the highest values were obtained under treatments $D, A, B$ and $C$, respectively. Mulching affected grain yield non-significantly, but the highest grain production was observed in treatment of C (3034.2 Kg/fed.), and minimum in 
treatment of B (2401.1 Kg/fed.). It was concluded that plastic mulch is the best method to save water under surface irrigation system.

\section{INTRODUCTION}

ile River is the main source of fresh water in Egypt. It supplies
$55.5 \mathrm{BCM} / \mathrm{yr}$ of freshwater every year, which represents $97 \%$ of
all renewable water resources in Egypt (Minsitry of Water Resources and Irrigation, 2005). One of the main objective of the Egyption sustainable agriculture development is increasing crop productivity per unit of water use and to improve on farm irrigation effciency. Recent studies indicate that, by year 2025, severe water scarcity will effect one-third of the population in development countries as there will be insufficient water resources to cover agriculture, domestic, indusrtial and environmental needs. Surface irrigation is the traditional method (about $80 \%$ of the irrigated area in Egypt), and it generally has a lower application efficiency (about $50 \%$ ) than other method mainly because of water loss due to deep percolation, which lead to rising ground water tables and leaching of nutrients (Swelam and Atta, 2009). Consequently, deep percolaction has a negative effect on crop yield, fertilizer requitrements and efficient water use (Donahue et al. 1977). Farmers commonly over-irrigate their fields, with greater losses. Therefore, the compination among mulching, cutting-off, and irrigation scheduling methods is one optimal method to save water and allivate water scarcity. The practice of spreading plastic sheet or any other material like straw on the soil surface to reduce water losses is called mulching. Furrow irrigation in combination with plastic mulch is a highly efficient water-saving irrigation technology (Chen and Feng, 2013). Soil mulching with plastic film, which results in reduced water loss and more even regulation of soil temperature, has been widely used in agriculture (Zhang et al., 2005). While, Rathore et al. (1998) reported that more water conserve in the soil profile during the early growth period with straw mulch than without it. Morever, straw mulching (SM) systems can conserve soil water and reduce temperature because they reduce soil disturbance and increase residue accumulation at the soil surface (Baumhardt and Jones, 2002; Zhang et al., 2009). Irrigation scheduling minimizes water-logging problems by reducing the drianage 
requirements and control root zone salinity problems through controlled leaching. Enviromental irrigation benefits of irrigation scheduling e.g. reduced losses of fertilizers resulting from a decrease in seepage increase in the soil (Mao, 1996); Nevertheless, in recent years there has been a wide range of proposed novel approaches to irrigation scheduling which have not yet been widely adopted; many of these are based on sensing the plant reponse to water dificits rather than sensing the soil mositure status directly (Jones, 1990).Optimal length of irrigation run at which watering should be stopped instead of irrigation till the tail end of the furrows . Such procedure resulting in reducing amounts of water pathways and the advancement movement of the accumulated water after stopping irrigation used in watering the remaining un-irrigated area. Soares et al. (2000) declared that for continuous and cutting-back irrigation, the application efficiency increased with the discharge, reaching a maximum value and decreased thereafter, the runoff loss increased and the deep percolation loss decreased as the discharge increased. Puustinen et al. (2005) found that mulching contributes to decrease runoff flow and enhance infiltration. While, García-Orenes et al. (2009) observed that time to ponding was delayed after straw mulching treatment respect to other types of management, as systemic herbicide or ploughing. Under field conditions, water is generally supplied to individuals furrows via siphon tubes or gated pipes, with the intent being to set inflow rates uniformly on a set of equal length furrows. Trout and Mackey (1988) measured inflow rate variability of $15 \%$ for siphon tube, $25 \%$ for gated pipe, and $29 \%$ for feed ditch water application techniques. Mulches improve both irrigation efficiences of water use and water application. Deng et al. (2006) reported that mulching with crop residues improve WUE by 10-20\% where straw mulching increased WUE of maize from 1.55 to $1.84 \mathrm{Kg} . \mathrm{m}^{-3}$. Which, Awan and Ali (1988) evaluated that application efficiency at farmers' field and reported that the application efficiency ranged from 34 to 95 percent.

\section{MATERIALS AND METHODS}

\section{1- Location and soil analysis}

Field study was conducted during Summer season of 2012 at El-Karada Water Research Station, Water Management and Irrigation Systems 
Research Institute, Kafr El-Sheikh, Egypt which located at Latitude of $31^{\circ} 03^{\prime} \mathrm{N}$ and Longitude of $30^{\circ} 57^{\prime} \mathrm{E}$. The soil was totally clay, with physical and chemical properties as shown in table (1).

\section{2- Experimental Design}

Experimental field consistes of four treatments as follow:

(1) No mulch (control) (A)

(2) Straw mulch (B)

(3) $30 \%$ plastic mulch (C)

(4) $60 \%$ plastic mulch (D)

Table (1) Some soil physical and chemical properties:

\begin{tabular}{|c|c|c|c|c|c|c|c|c|c|c|}
\hline $\begin{array}{l}\text { Depth } \\
(\mathrm{cm})\end{array}$ & $\begin{array}{c}\text { Sand } \\
\%\end{array}$ & $\begin{array}{c}\text { Silt } \\
\%\end{array}$ & $\begin{array}{c}\text { Clay } \\
\%\end{array}$ & 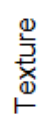 & $\begin{array}{c}\text { Bulk } \\
\text { density } \\
\left(\mathrm{g} \mathrm{cm}^{-3}\right)\end{array}$ & $\begin{array}{c}\text { Field } \\
\text { Capacity } \\
(\%)\end{array}$ & $\begin{array}{c}\text { Wilting } \\
\text { point } \\
(\%)\end{array}$ & $\begin{array}{c}\text { Avaliable } \\
\text { water } \\
(\%)\end{array}$ & $\begin{array}{c}\text { E.C } \\
\left(\mathrm{dS} \cdot \mathrm{m}^{-1}\right)\end{array}$ & $\mathrm{pH}$ \\
\hline $00-20$ & 16.50 & 23.60 & 59.90 & \multirow{5}{*}{$\frac{\hat{\pi}}{\tilde{N}}$} & 1.19 & 38.00 & 18.00 & 20.00 & 1.75 & 7.80 \\
\hline $20-40$ & 10.00 & 25.00 & 65.00 & & 1.29 & 39.54 & 19.00 & 20.54 & 1.88 & 8.00 \\
\hline $40-60$ & 10.00 & 20.00 & 70.00 & & 1.31 & 40.50 & 20.50 & 20.00 & 2.20 & 7.90 \\
\hline $60-80$ & 09.00 & 24.00 & 67.00 & & 1.36 & 41.00 & 21.00 & 20.00 & 2.23 & 8.10 \\
\hline Average & 11.38 & 23.15 & 65.48 & & 1.29 & 39.76 & 19.63 & 20.14 & 2.02 & 7.95 \\
\hline
\end{tabular}

Each treatment contains of four furrows. The length of furrows was $60 \mathrm{~m}$ with spacing $0.70 \mathrm{~m}$ as shown in Fig. (1). Mulching was performed in the cross sectional of furrow channle (furrow perimeter) along $50 \%$ of furrows length. Two different materials were used under experimental treatments; rice straw and plastic sheet. Rice straw was added with a rate of 50 gram. $\mathrm{m}^{-1}$ of furrow. On the other hand, plastic sheet (PS) was applied with different dimintions under two treatments were $\mathrm{C}$ and $\mathrm{D}$ as shown in table (2).

Table (2) Calculation of Total applied plastic sheet for experimental treatments:

\begin{tabular}{ccccc}
\hline & $\begin{array}{c}\text { Furrow } \\
\text { perimeter } \\
(\mathrm{m})\end{array}$ & $\begin{array}{c}\text { mulched percentage of } \\
\text { furrow perimeter } \\
\text { Treatments }\end{array}$ & $\begin{array}{c}\text { Mulched } \\
\text { furrow length } \\
(\mathrm{m})\end{array}$ & $\begin{array}{c}\text { Total amount } \\
\text { of PS } \\
\left(\mathrm{m}^{2} \text {.furrow }{ }^{-1}\right)\end{array}$ \\
\hline $30 \%$ plastic mulch $(\mathrm{C})$ & 0.7 & 30 & 30 & 6.3 \\
$60 \%$ plastic mulch (D) & 0.7 & 60 & 30 & 12.6 \\
\hline
\end{tabular}




\section{3- Irrigation scheduling}

\section{3-1- Applied Irrigation Water (AIW)}

Irrigation water was applied using for each treatment with a spile. Actual applied irrigation water was calculated by the following equation ( Eid, 1998).

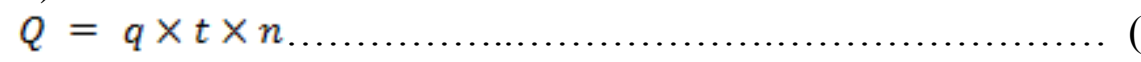

$Q=$ Applied irrigation water, $\mathrm{m}^{3} / \mathrm{fed}$

$q=$ Discharge $\mathrm{m}^{3} / \mathrm{min}$,

$t=$ Total irrigation time, $\mathrm{min} / \mathrm{fed}$, and

$n$ Number of irrigation per season.

The gross irrigation water depth was estimated for each treatment and was calculated by the following equation (Brouwer et al 1989).

$$
\mathrm{d}_{\mathrm{g}}=\frac{\mathrm{d}_{\mathrm{n}}}{\mathrm{E}_{\mathrm{i}}(1-\mathrm{L} \cdot \mathrm{R})}
$$

Where:

$d_{g}=$ Gross irrigation depth, $\mathrm{cm}$

$d_{n}=$ Net application depth, $\mathrm{cm}$

$E_{i}=$ Irrigation water efficiency, \%

$L R=$ Leaching requirements, $\%$

\section{3-2- Irrigation intervals}

Tensiometers were used to schedule irrigation at three depths 10, 20 and $40 \mathrm{~cm}$ for each treatment. Irrigation water was supplied when management allowable depletion (MAD) approached $50 \%$. Maximum depth of maize root zone was $0.70 \mathrm{~m}$. Tensiometers on depths 10 and 20 $\mathrm{cm}$ were installed in intial stage, while, the other depth $40 \mathrm{~cm}$ was installed in the mid season stage.

\section{4- Advance time and cut off}

Water advance time (WAT) was measured at each treatment every $10 \mathrm{~m}$ along furrows length. On the other cutting off was perfomed when water reaches $85 \%$ of furrow length.

\section{5- Soil Mositure Content (SMC)}

Soil moisture content (SMC) was measured for each treatment at depths $0-20,20-40,40-60 \mathrm{~cm}$ and $60-80 \mathrm{~cm}$ using gravimetric method. It 
was measured at three locations $\mathrm{X}, \mathrm{Y}$ and $\mathrm{Z}$ along cross sectional of furrow channel as shown in Fig. (2).

\section{Guidelines}

1) Treatments

|A] No-mulch

B Straw mulch

[C] $30 \%$ plastic mulch

D] $60 \%$ plastic mulch

\section{2) Devices}

Tensiometers
$10 \mathrm{~cm}$
$20 \mathrm{~cm}$
Observation weI
Spile

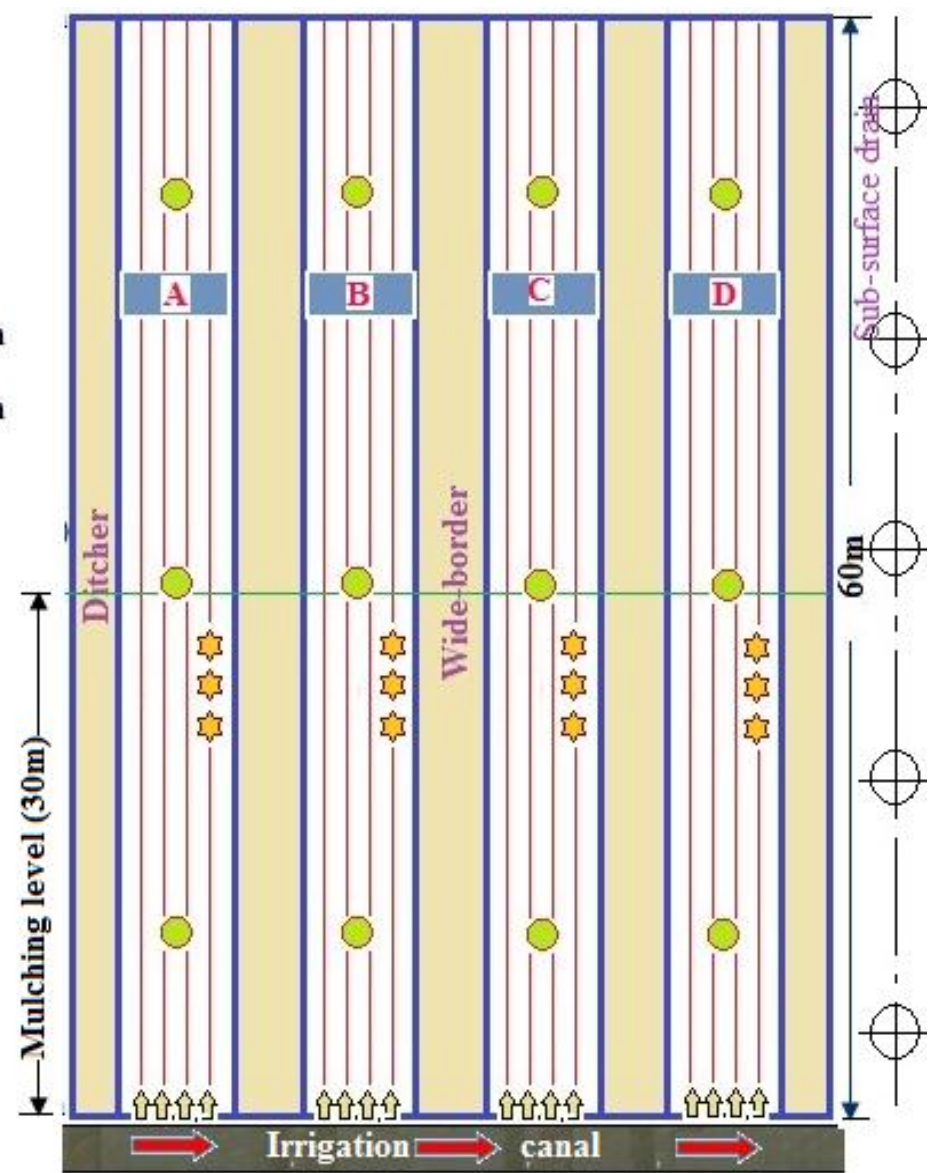

Fig. (1) Schematic diagram of experimental field treatments in detail.

\section{6- Irrigation water efficiencies}

\section{6-1- Water Use Efficiency ( WUE)}

Water use efficiency was calculated for different treatments after crop harvest according to Eq. (3) (Jensen, 1983).

WUE $=\frac{\text { Grain yield }\left(\mathrm{kg} \mathrm{fed}^{-1}\right)}{\text { Water applied }\left(\mathrm{m}^{3} \mathrm{fed}^{-1}\right)}$ 


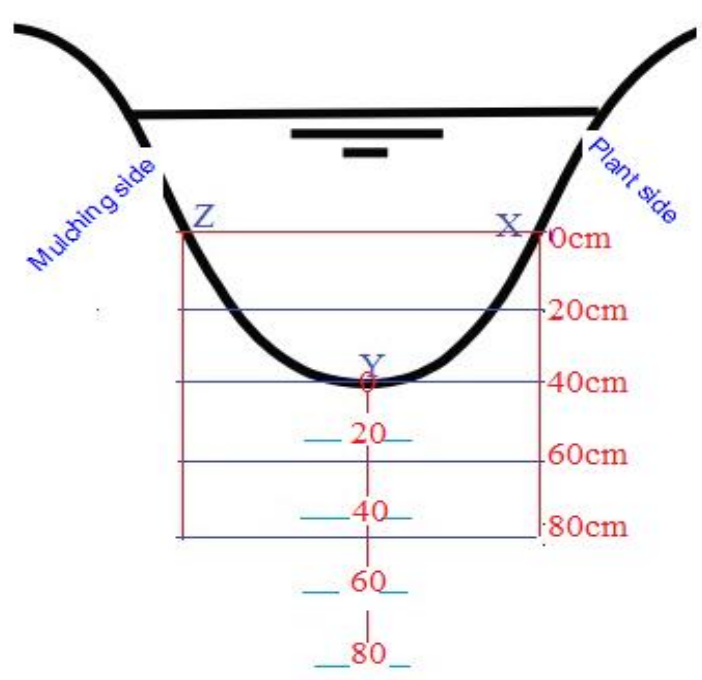

Fig. (2) Locations of measuring moisture content.

\section{6-2- Water application efficiency}

It was calculated according to Eq. (4).

$\mathrm{E}_{\mathrm{a}}=\left(\mathrm{cu} / \mathrm{W}_{\mathrm{a}}\right) \times 100$

Where:

$\mathrm{E}_{\mathrm{a}}=$ Water application efficiency (\%)

$\mathrm{cu}=$ Irrigation water stored in the root zone $(\mathrm{mm})$

$W_{a}=$ Irrigation water delivered to the farm or field (mm).

\section{7- Ground Water Level (GWL)}

It measured at each treatments at three location as shown in Fig. (1). The locations were $\mathrm{X}, \mathrm{Y}$, and $\mathrm{Z}$. It located on 12,30 , and $48 \mathrm{~m}$ along treatments length respectively.

\section{8- Grain yield (GY)}

Three plants within three replications at each treatment were randomly selected. Total grain yield was calculated using multiplied by a number of the plants in feddan (24000 plant/fed).

\section{RESULTS AND DISCUSSION}

\section{1- Irrigation scheduling}

\section{1-1- Applied irrigation water}

Results in table (3) showed that the highest amount of applied irrigation water was obtained under treatments of B, A, C and D, respectively. It 
was observed that both treatments of $\mathrm{D}$ and $\mathrm{C}$ reduced irrigation water with about of $24.65 \%$ and $21.65 \%$ compared to the treatment of $\mathrm{A}$, respectively. On the other hand, the treatment of B increased the applied irrigation water with about of $3.37 \%$ than the treatment of $\mathrm{A}$, as shown in Fig.(3).

\section{1-2- Irrigation intervals}

Results of soil water potential (SWP) were obtained as shown in the following figures 4, 5, 6 and 7. Results showed that five irrigation applications were added to the field. It was observed that SWP was significantly affected by mulching under depths 10 and $20 \mathrm{~cm}$ because most of maize roots concentrate under this layer which leads to increase Evapotranspiration and increase infiltration. On the other hand, SWP had non-significantly changes under depth of $40 \mathrm{~cm}$ due to the rising of ground water tables which leads to increase soil water content under this layer.

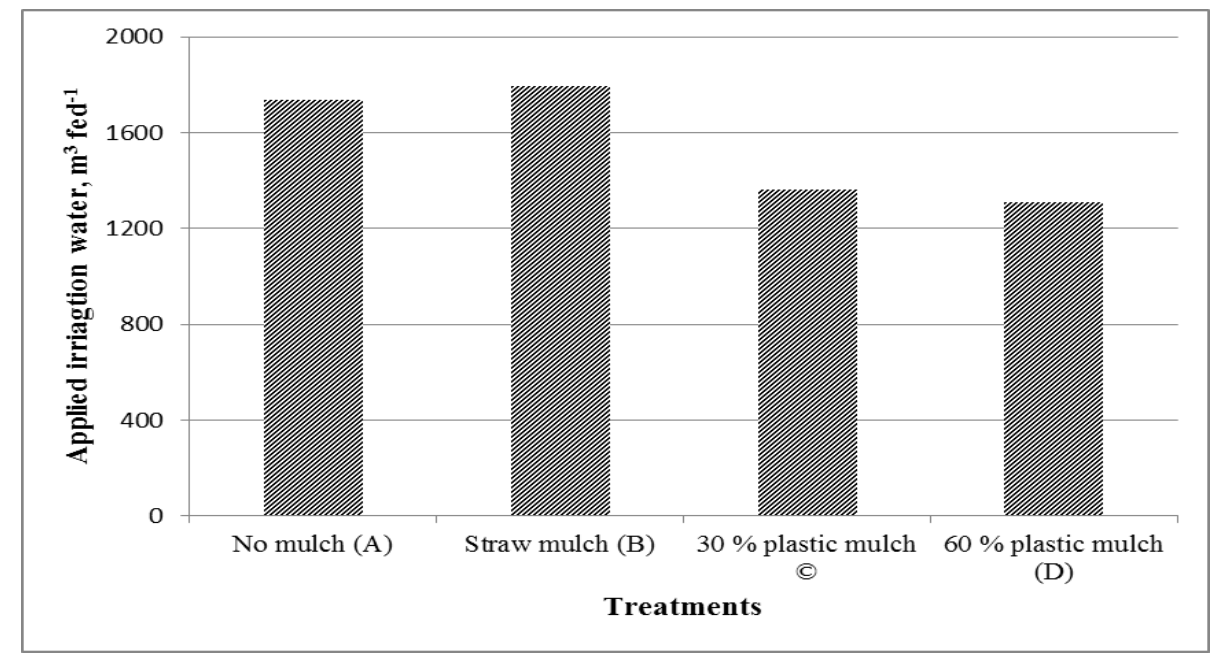

Fig. (3) Diagram showing percentages of applied irrigation water to main experimental field.

As can be seen in the following figures 4, 5, 6 and 7 that highest values of SWT at 10 and $20 \mathrm{~cm}$ depths were obtained under treatments of A, D, $\mathrm{B}$ and $\mathrm{C}$, respectively. While, the highest values of SWT at $40 \mathrm{~cm}$ depth were obtained under C, A, B and D, respectively. 


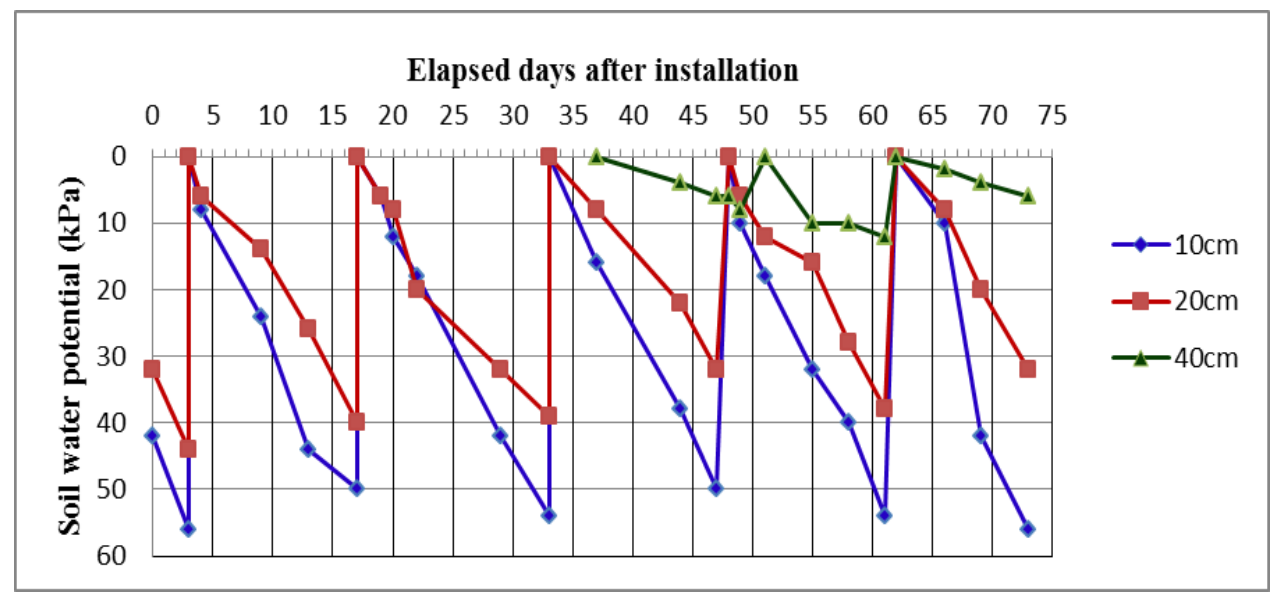

Fig. (4) Soil water potential under treatment of no mulch (A).

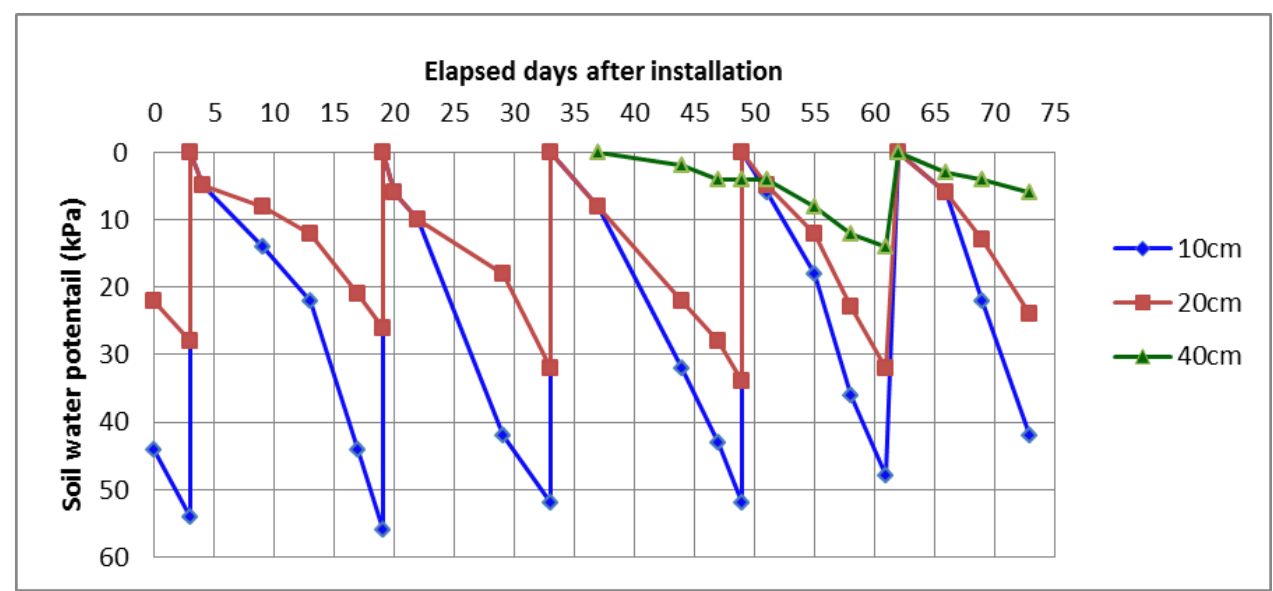

Fig. (5) Soil water potential under treatment of of straw mulch (B).

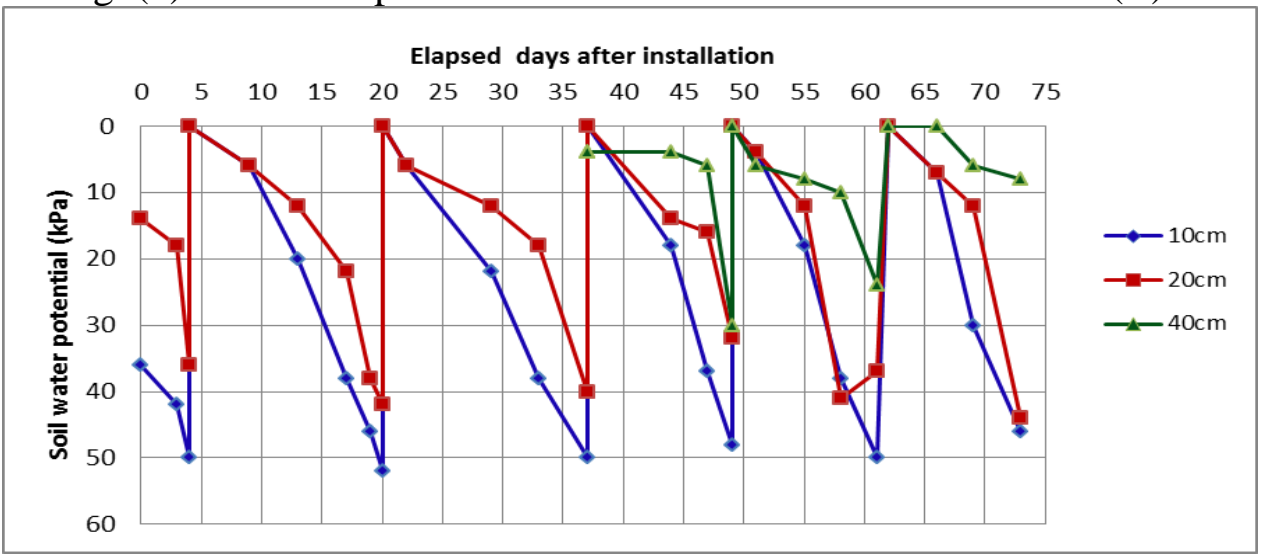

Fig. (6) Soil water potential under treatment of $30 \%$ plastic mulch (C). 


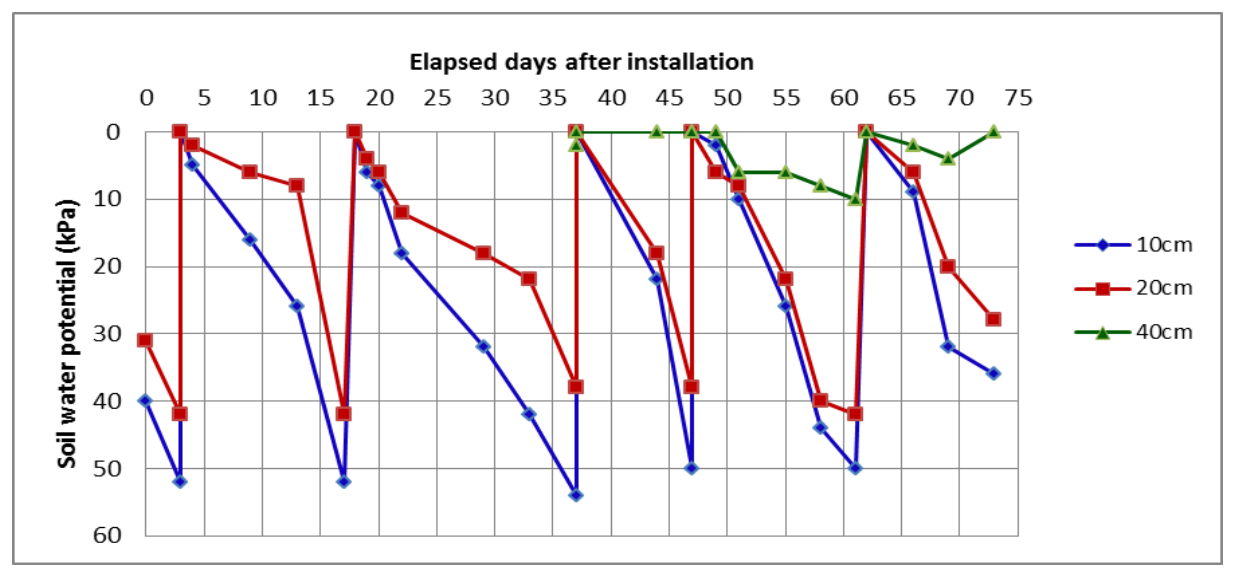

Fig. (7) Soil water potential under treatment of $60 \%$ plastic mulch (D).

\section{1-3- Relationship between estimated and actual applied irrigation water}

Applied irrigation water (AIW) was estimated from irrigation scheduling data, and also actual AIW was measured with a spile. Results indicated that there is a big difference between estimated and actual values of applied irrigation water as shown in Fig. (8). It was observed that treatments $\mathrm{A}$ and $\mathrm{B}$ invistigated the highest values of actual AIW, but lower than values of estimated AIW under the same treatments due to the performance of cutting off. On the other hand, treatments $\mathrm{C}$ and $\mathrm{D}$ invistigated the lowest values of actual AIW due to the performance of cutting off and plastic sheet leads to prevent water to infiltrate into soil.

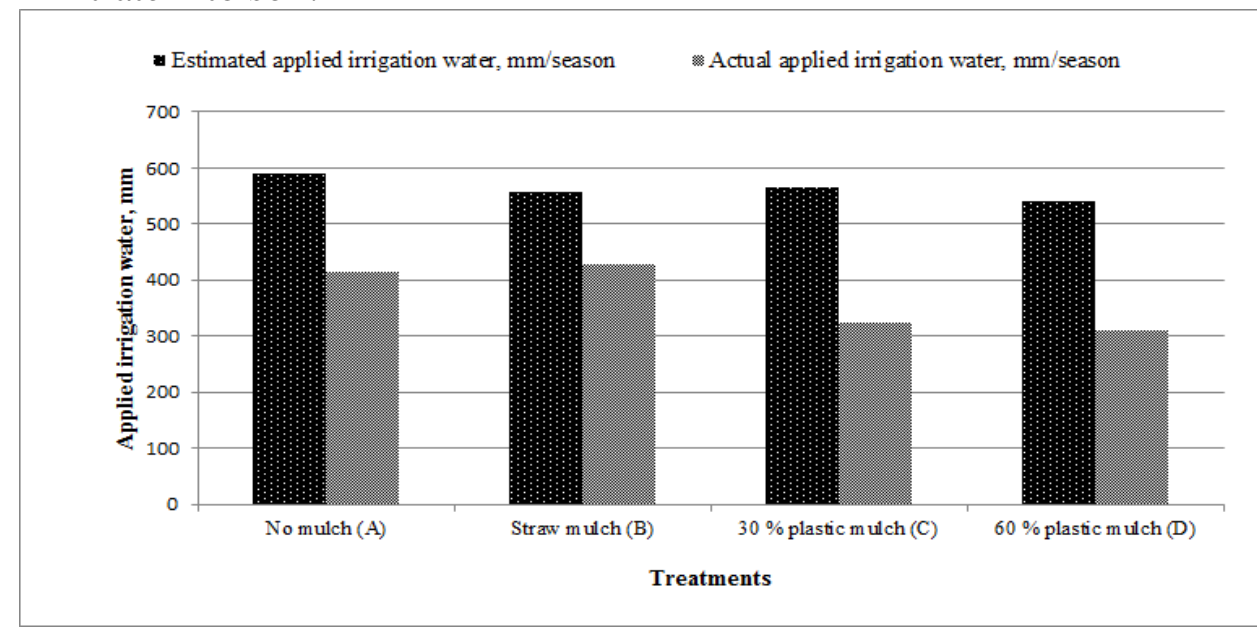

Fig. (8) Relationship between estimated and actual applied irrigation water 


\section{2- Advance time}

Results indicate that both treatments 30 and $60 \%$ plastic mulch reduced advance time with 20.9 and $21.3 \%$ compared to control treatment, respectively. While, the treatment of straw mulch increased the advance time with $19.1 \%$ compared to control treatment as shown in figures (9,10,11 and 12). This is in agreement with other findings reported by several authors. Puustinen et al. (2005) found that mulching contributes to decrease runoff flow and enhance infiltration. García-Orenes et al. (2009) observed that time to ponding was delayed after straw mulching treatment respect to other types of management, as systemic herbicide or ploughing.

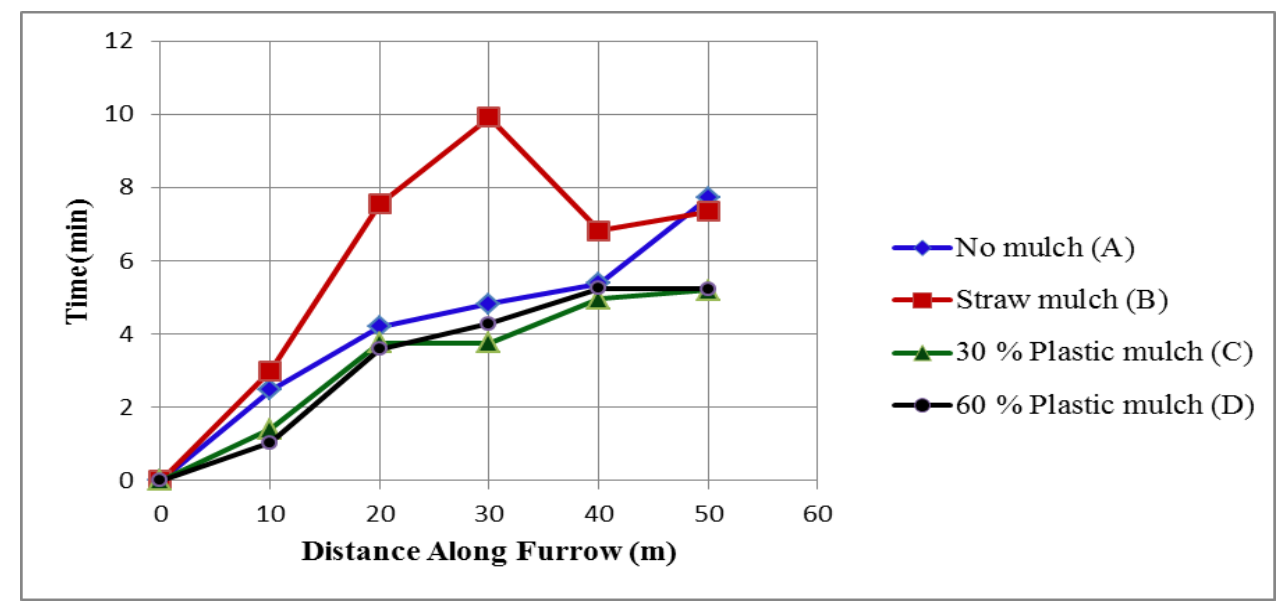

Fig. (9) Effect of mulching on advance time during first irrigation

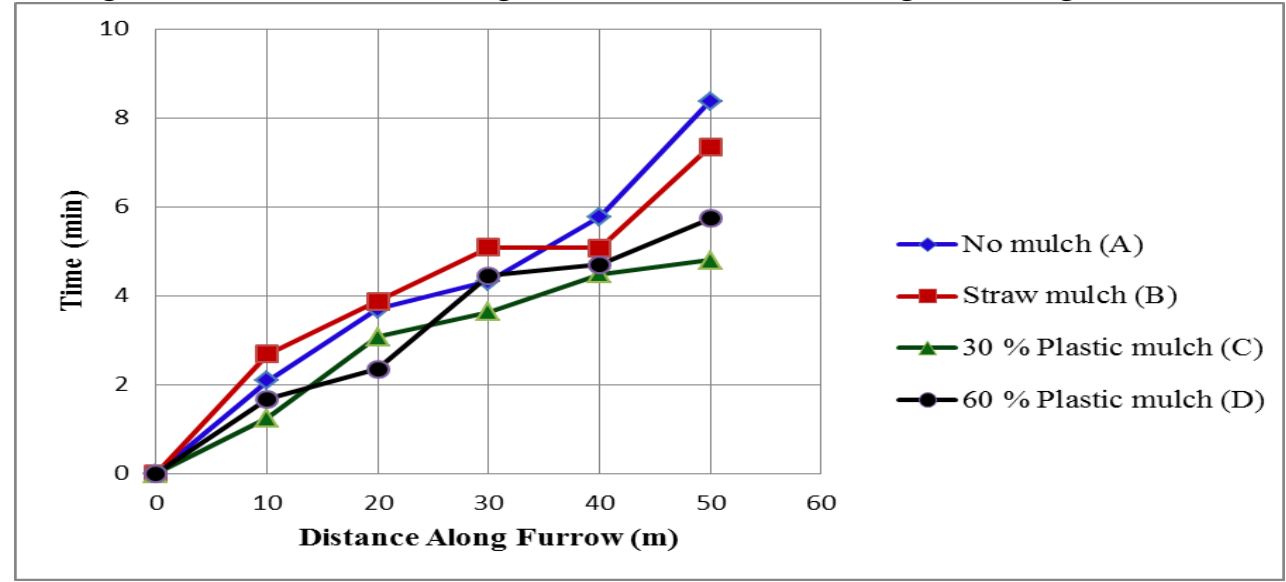

Fig. (10) Effect of mulching on advance time during second irrigation 


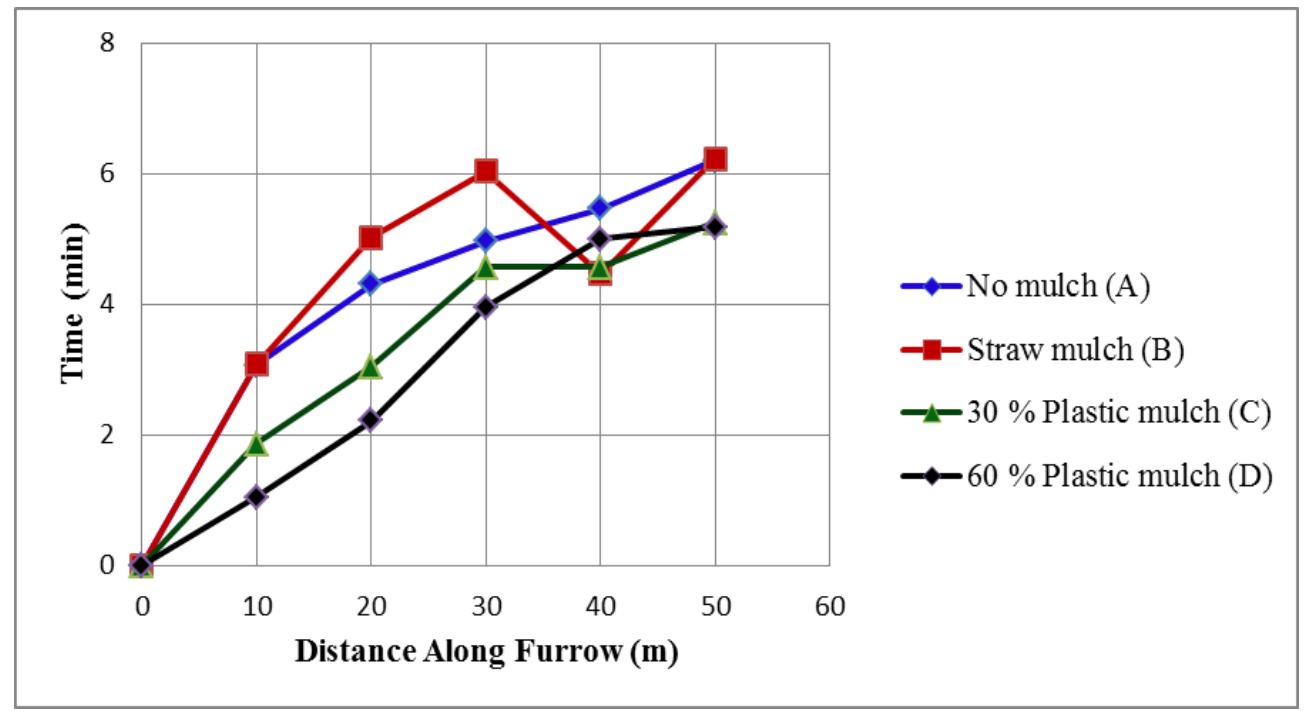

Fig. (11) Effect of mulching on advance time during third irrigation

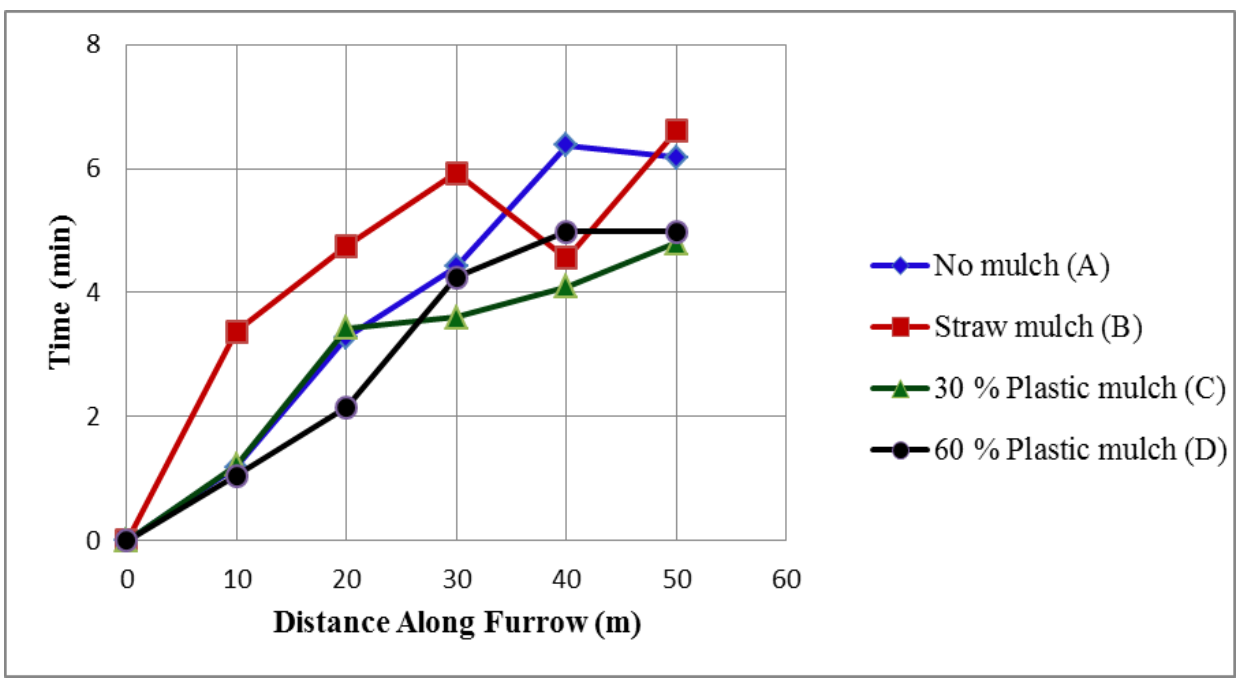

Fig. (12) Effect of mulching on advance time during fourth irrigation

\section{3- Soil Mositure ontent (SMC)}

Results in Fig. (13) showed that both treatments D and C reduced SMC at locations $\mathrm{Y}$ and $\mathrm{Z}$, while, the highest values of SMC were obtained under straw mulch treatment. These results agree with the findings of several authors, for example, Ji and Unger (2001) reported increases in soil moisture storage by using straw mulch. 


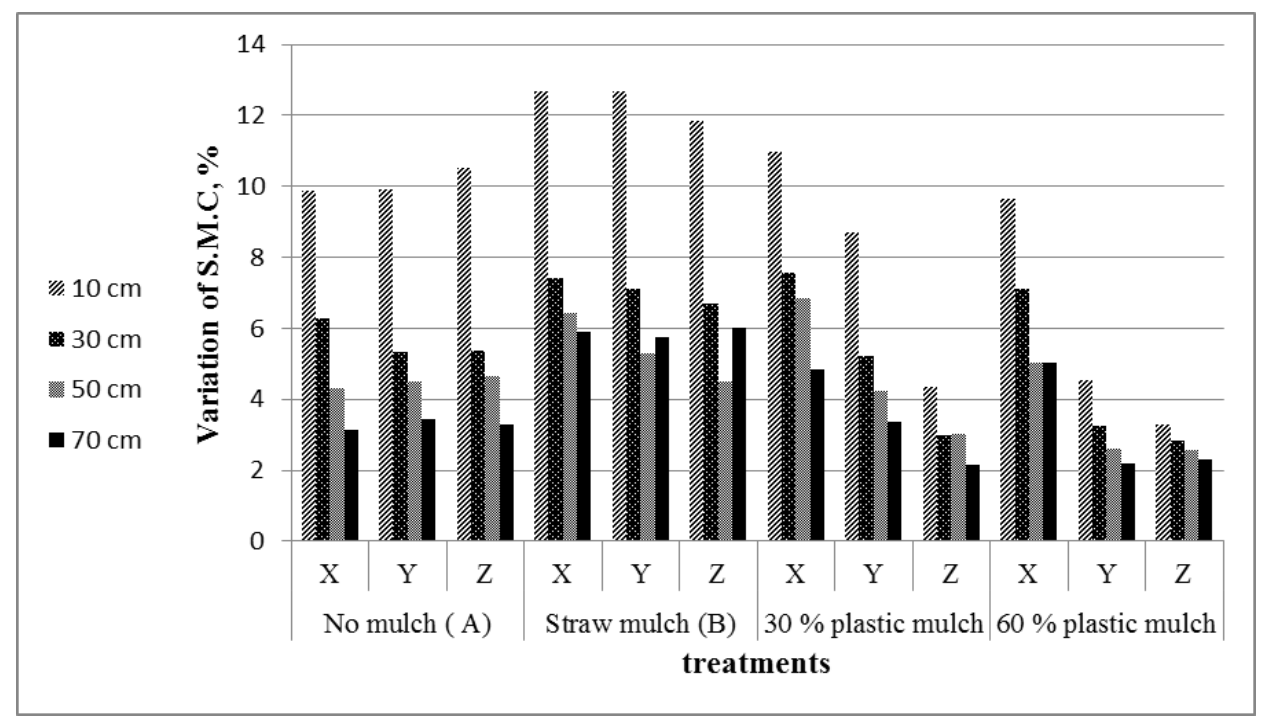

Fig. (13) Effect of mulching on mositure content variation before and after irrigation.

\section{4- Irrigation efficiencies}

\section{4-1- Water Use Efficiency (WUE)}

Water use efficiency investigated significantly differences among whole experimental treatments. Value of WUE were (2.23, 2.09, 1.69 and 1.34 $\mathrm{Kg}$. Fed ${ }^{-1}$ ) under treatments of $\mathrm{C}, \mathrm{D}, \mathrm{A}$ and $\mathrm{B}$, respectively as shown in Fig. (14). Straw mulch treatment had the lowest value of WUE due to the increasment of ground water table which rises upward and compine with rice straw. Basically, straw is an organic matter which absorbed irrigation water under the rooting system of maize which leads to reduce plant transpiration.

\section{4-2- Application water efficiency $\left(E_{a}\right)$}

Mean values of application water efficiency were estimated for whole applications of irrigation. Results indicated that values of $E_{a}$ were (63.62, $59.15,56.10$ and $53.10 \%$ ) under treatments C, D, A and B, respectively as shown in Fig. (15). These results agree with the findings of Wolters and Berisavljevic (1991), reported that field application efficiency is influenced by factors such as soil type, irrigation application method. Values of application efficiency are mostly similar to results were obtained by Awan and Ali (1988) who evaluated application efficiency at 
farmers' field and reported that the application efficiency ranged from 34 $\%$ to $95 \%$.

\section{5- Ground water level (GWL)}

Ground water level was measured at three locations per treatment X, Y and $\mathrm{Z}$ for both of two stages (experimental test and main experimental field).

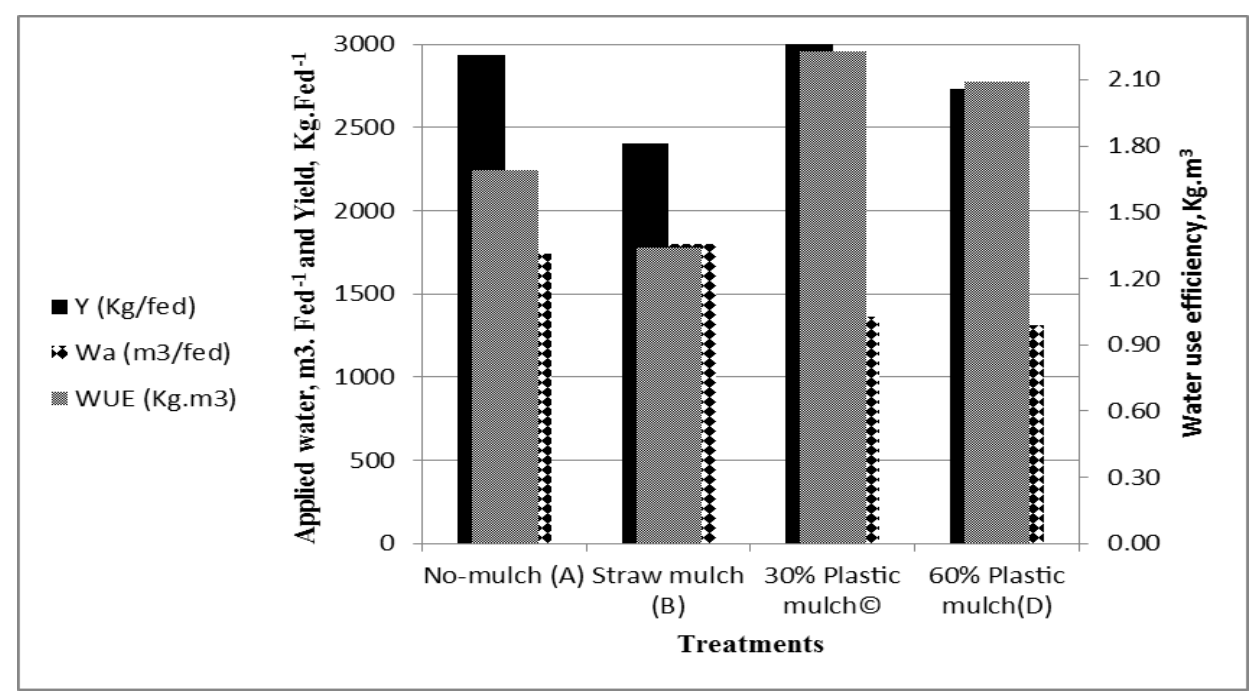

Fig. (14) Effect of mulching on water use efficiency of maize.

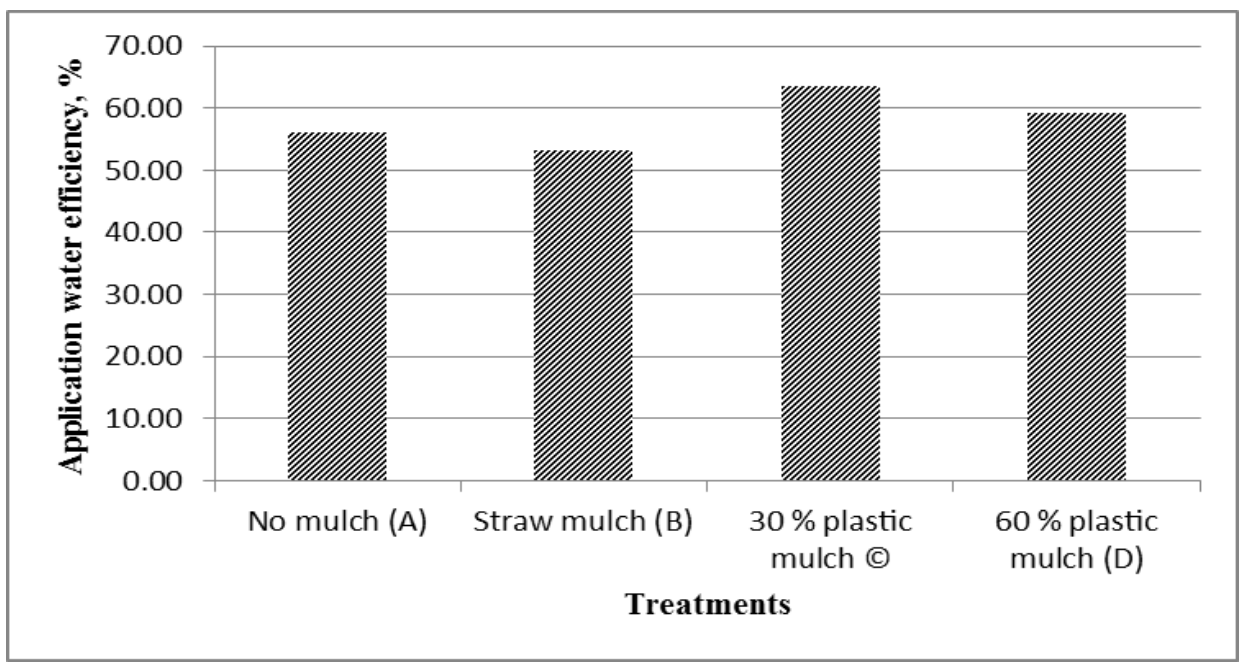

Fig. (15) Effect of mulching on application irrigation water efficiency of maize. 
According to location $\mathrm{X}$, it was observed that GWL investigated the highest values under treatments of $\mathrm{A}, \mathrm{D}$, and $\mathrm{B}$, respectively. On the other hand, the lowest values were obtained under the treatment of $\mathrm{C}$, as shown in Fig. (4.16).

According to location $\mathrm{Y}$, in experimental test (before sowing), the highest values of GWL were obtained under treatments of B, A, D, and $\mathrm{C}$, respectively. During intial and mid stages, GWL invistigated the highest values under treatments of $\mathrm{A}, \mathrm{B}, \mathrm{D}$ and $\mathrm{C}$, repectively. Moreover, in late stage, the highest values of GWL were obtained under treatments of A, D, C, and B, respecively, as shown in Fig. (4.17).

According to location $\mathrm{Z}$, values of ground water level during ( experimental test, intial and mid stages) were the highest under treatments $\mathrm{D}, \mathrm{C}, \mathrm{B}$, and $\mathrm{A}$, respectively. On the other hand, in late stage, the highest values of GWL were obtained under treatments of D, A, C, and B, respectively, as shown in Fig. (4.18).

\section{6- Grain yield (GY)}

Mulching affected grain yield non-significantly as shown in table (3). Highest value of grain yield production was observed in treatment of $\mathrm{C}$ (3034.2 Kg/fed.), while, the lowest value was obtained under treatment of B (2401.1 Kg/fed.). This is due to increase soil water storage under straw mulch treatment to trigger the accumulation of salts in root zone with negative effects on crop productivity.

Table (3) Effect of mulching methods on maize grain yield.

\begin{tabular}{|c|c|}
\hline Treatment & Grain yield (Kg/fed.) \\
\hline No mulch (A) & 2936.7 \\
\hline Straw mulch (B) & 2401.1 \\
\hline $30 \%$ plastic mulch (C) & 3034.2 \\
\hline $60 \%$ plastic mulch (D) & 2733.9 \\
\hline
\end{tabular}




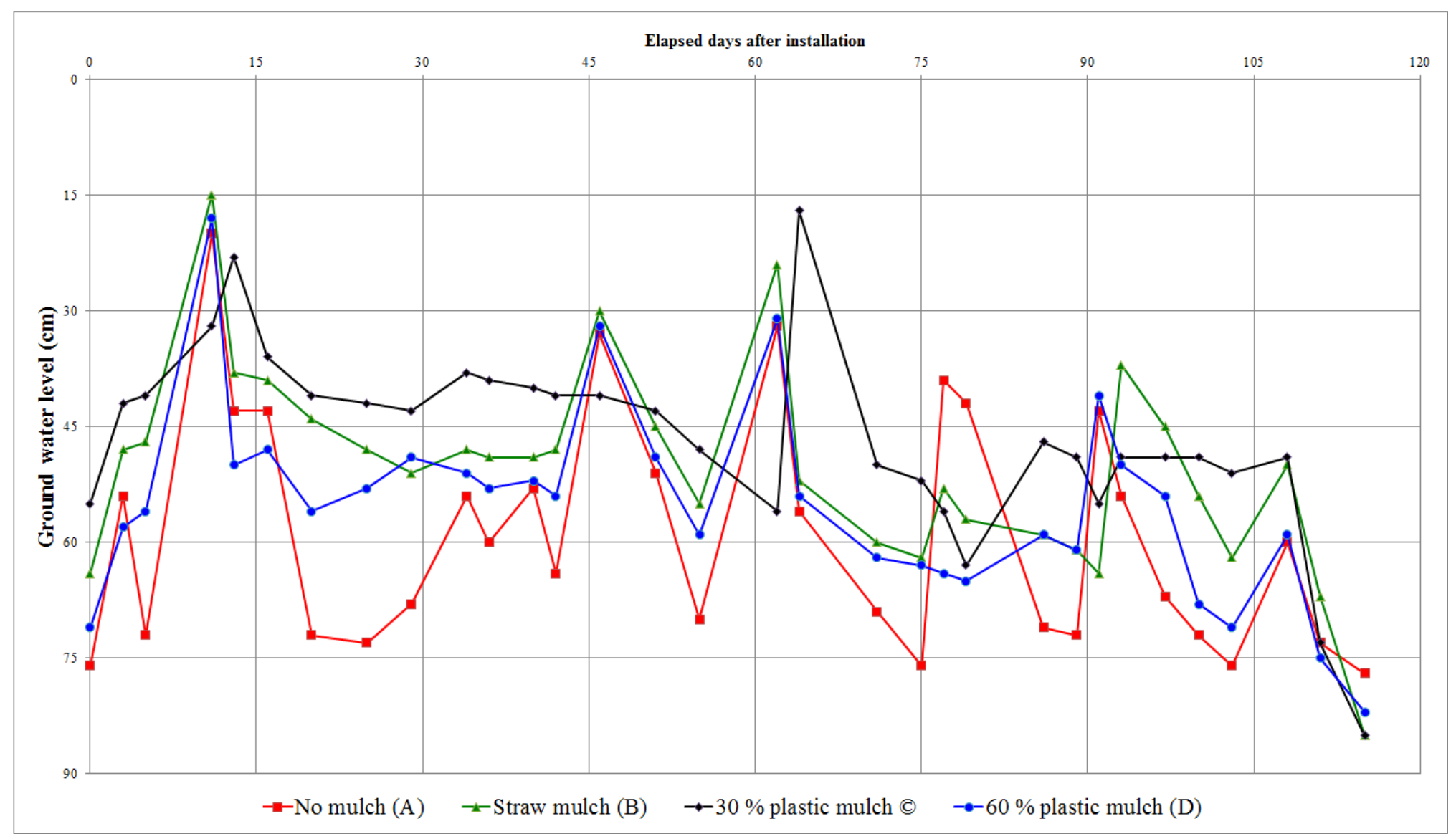

Fig. (16) Effect of mulching method on ground water level at location $\mathrm{X}$ 


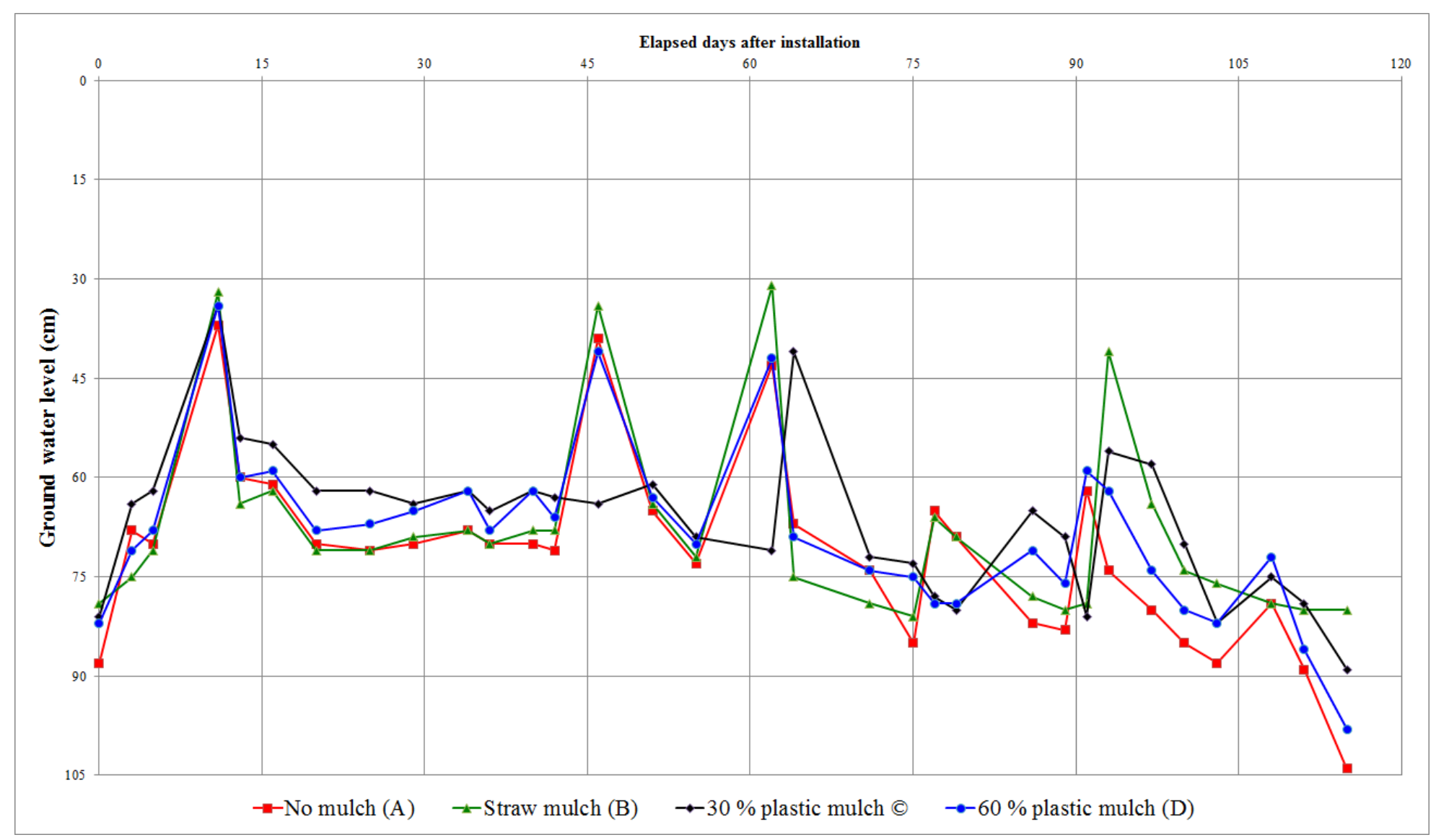

Fig. (17) Effect of mulching method on ground water level at location Y 


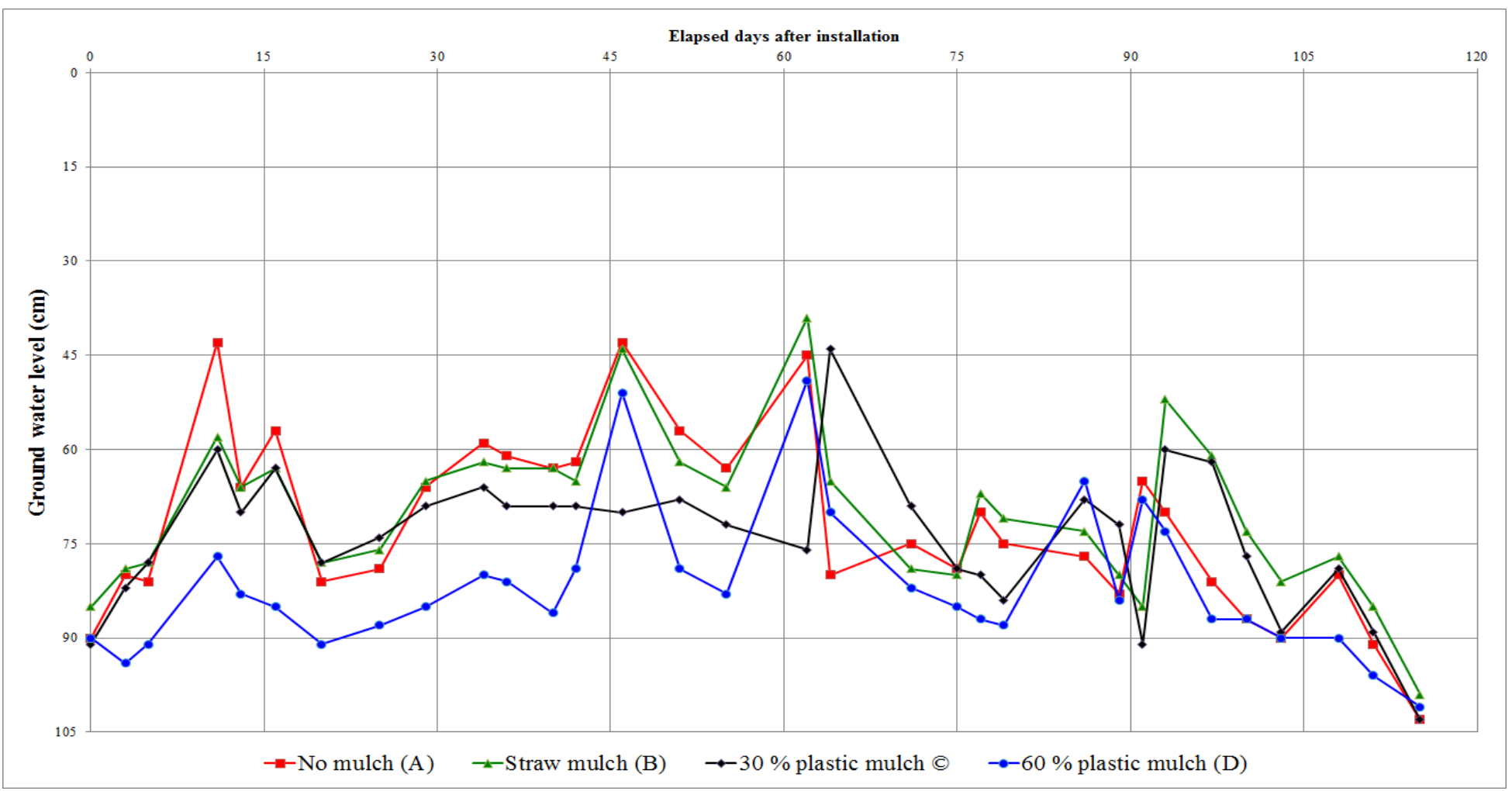

Fig. (18) Effect of mulching method on ground water level at location Y 


\section{CONCLUTION}

Plastic mulch is effective method on irrigation water saving. It can be control weeds as observed during the experimental test. It saves the applied irrigation water and control erosion. It conserves soil moisture content within soil profile. It controls ground water table so reduces soil salinity. It improves both irrigation water use and application efficiencies. Also, it increases grain yield production of maize.

\section{REFERENCES}

Awan, Q.A. and A. Ali. 1988. Irrigation efficiencies in the farm irrigation system: Water as a constraint. Univ. of Agric. Faisalabad.

Baumhardt R.L., and O. R. Jones. 2002. Residue management and tillage effects on soil-water storage and grain yield of dryland wheat and sorghum for a clay loam in Texas. Soil Till. Res. 68: 71-82.

Brouwer, C., K. Prins, and M. Heibloem. 1989. Irrigation Scheduling. FAO Irrigation Water Management, Training manual no.4.

Chen, L., and Q. Feng .2013. Soil water and salt distribution under furrow irrigation of saline water with plastic mulch on ridge. $\mathrm{J}$ Arid Land 5(1): 60-70.

Deng, Xi-p., Shan, L., Zhang, H., and Turner, N.S., 2006. Improving agricultural water use efficiency in arid and semiarid areas of china. Agricultural Water Management 80, 23-40.

Donahue, R.L., R.W. Miller and J.C. Shickluna 1977. Soils: an introduction to soils and plant growth. Prentice. Hall. Inc. Englewood Cliffs. New Jeresy $076324^{\text {th }}$ edition pp. 383-393.

Eid, S.A. (1998). Surge flow irrigation for corn and wheat under different land leveling practices in heavy clay soils. $\mathrm{Ph}$. D. Thesis Soil Sc. Dept., Fac. of Ag. Kafr El-Sheikh, Tanta Uni., Egypt.

García-Orenes, F., Cerdà. A., Mataix-Solera, J., Guerrero, C., Bodí, M.B., Arcenegui, V., Zornoza, R., and Sempere, J.G., 2009. 
Effects agricultural management on surface soil properties and soil-water losses in eastern Spain. Soil \& Tillage Research 106: 117-123.

Jensen, M.C. 1983. "Organization Theory and Methodology." Accounting Re- view 50 (April 1983).

Ji, S., Unger, P.W. 2001. Soil water accumulation under different precipitation, potential evaporation, and straw mulch conditions. Soil Science Society of America Journal 65, 442- 448.

Jones, H.G. 1990. Plant water relations and implications for irrigation scheduling. Acta Horticulturae. 278: 67-76.

Mao, Z. 1996. Enviromental impact of water-saving irrigation for rice. In : Irrigation scheduling: From theory of practice. Proc. ICID/FAO workshop. Rome.

Minsitry of Water Resources and Irrigation, 2005. Integrated Water Resources Management plan. Page 9.

Puustinen, M., Koskiaho, J., and Peltonen, K., 2005. Influence of cultivation methods on suspended solids and phosphorus concentrations in surface runoff on clayey sloped fields in boreal climate. Agriculture, Ecosystems, and Environment 105, 565579 .

Rathore, A.L., A.R. Pal and K.K. Sahu, 1998. Tillage and mulching effects on water use, root growth and yield of rainfed mustard and chickpea grown after lowland rice. J. Sci. Food Agric ., 78: 149161.

Soares, A. A.; R. A. Oliveira; M. M. Ramos; A. Rasch and J. H. T. DAvila (2000). Cutting-back furrow irrigation design - a new methodology. 20 (2): 119-129.

Swelam, A., and Y. Atta. 2009. New approach of farm management under surface irrigation to improve water saving and productivity. New Horizons in Science \& Technology (NHS\&T), 1(3):76 -83. 
Trout, T.J., and B.E. Mackey. 1988. Furrow inflow and infiltration variability.Trans. ASAE, 31(2), 531-537.

Wolters, W. and G.K. Berisavljevic. 1991. Patterns and trends in field application efficiency. Int'l Commission on Irrig. and Drainage Bulletin. 40(2): 11-26.

Zhang, D.Q., Y.C. Liao, and Z.K. Jia. 2005. Research advances and prospects of film mulching in arid and semi-arid areas. Agric. Res. Arid Areas, 23(1): 208-213(in chinese with English abstract).

Zhang SL, Lövdahl L, Grip H, Tong YA, Yang XY, and Wang QJ (2009). Effects of mulching and catch cropping on soil temperature, soil moisture and wheat yield on the Loess Plateau of China. Soil Till. Res., 102: 78-86.

\section{الملخص العزبي - المي}

تقليل فواقد مياه الرى السطحى فى دلتا النيل

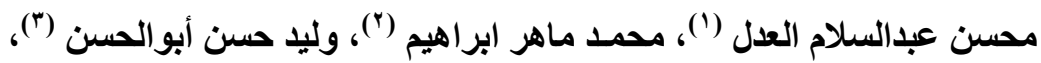

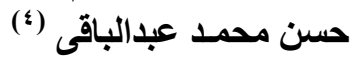

يعتبر الرى السطحى من أكثر نظم الرى الطرق انتشار ا فى مصر بل وفى وفى كل أنحاء

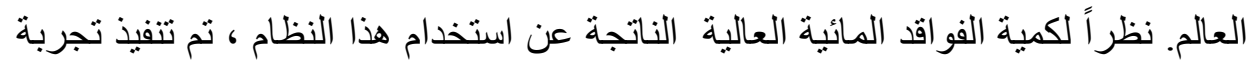

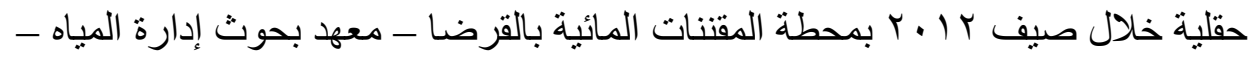

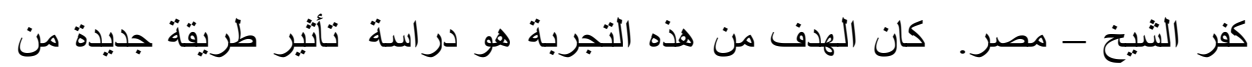

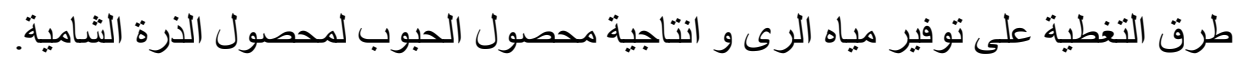

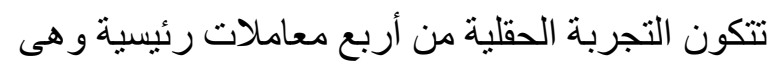

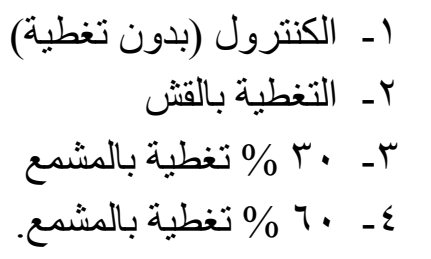

1. أستاذ دكتور بقسم الهندسة الزراعية / كلية الزراعة / جامعة المنصورة

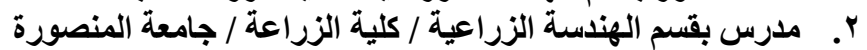

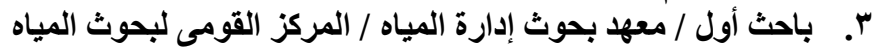

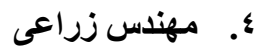


تم تنفيذ التغطية فى محيط الابتلال لخطوط الرى من الجهة المقابلة للنباتات وعلى امتداد •

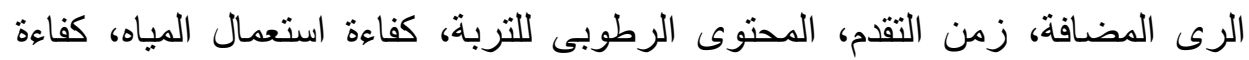

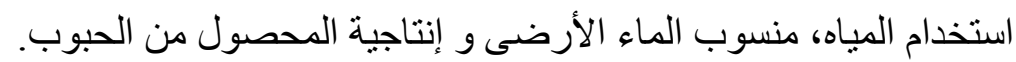

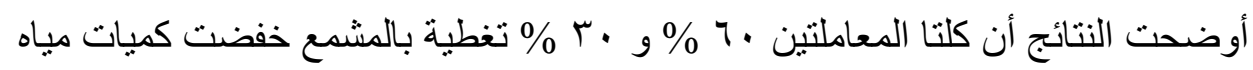

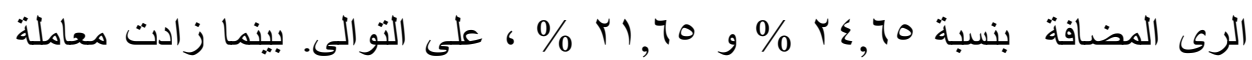

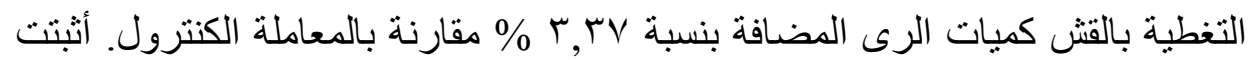

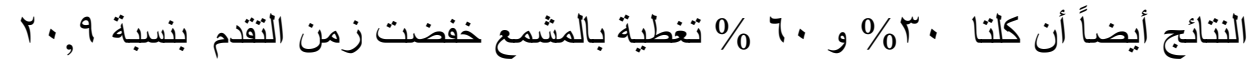

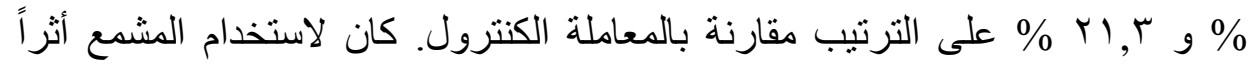

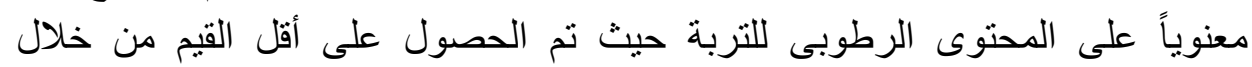

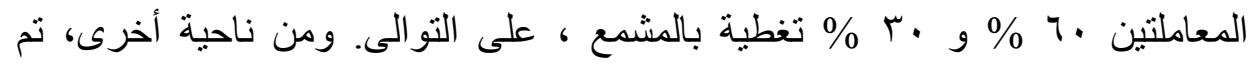

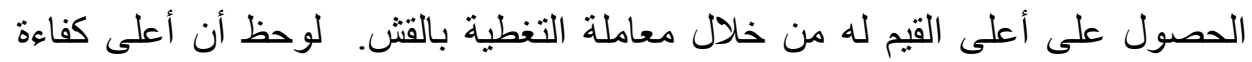

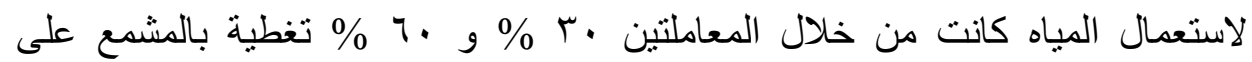

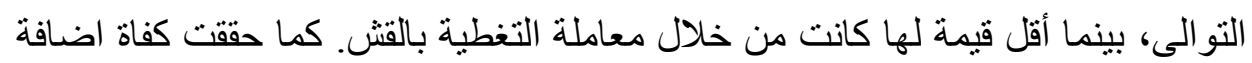

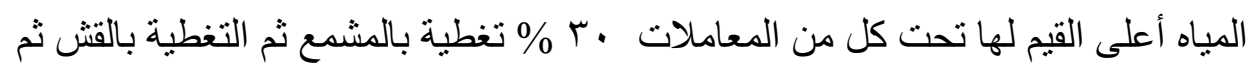
• .

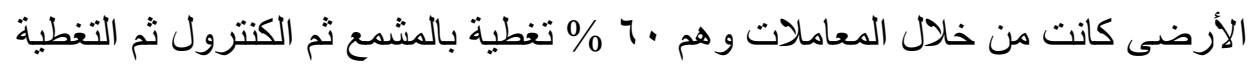

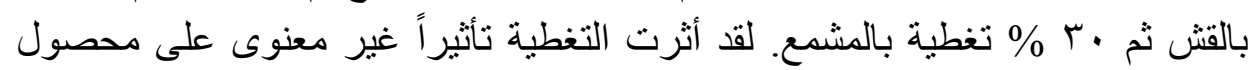

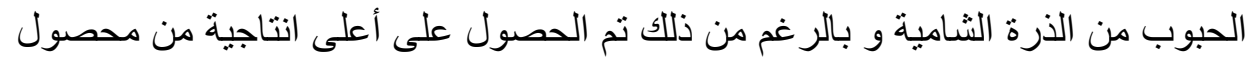

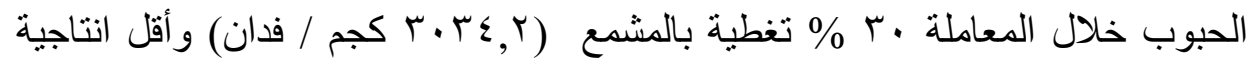

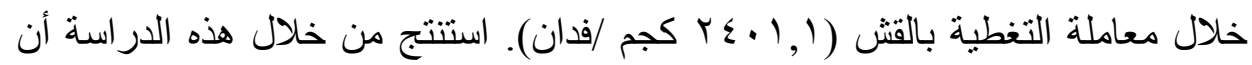

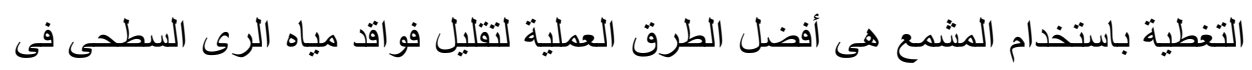
منطقة الدلتا. 